\title{
INFLUENCE OF NATURAL AND ANTHROPOGENIC FACTORS ON THE DISTRIBUTION OF XEROTHERMIC PLANTS IN THE LOWER SAN RIVER VALLEY (SE POLAND)
}

\author{
Rafal Krawczyk \\ Department of Nature Conservation, Maria Curie-Skłodowska University, \\ Akademicka 19, 20-033 Lublin, Poland, \\ e-mail: Rafal.Krawczyk@umcs.lublin.pl
}

Received: 27.09.2011

\begin{abstract}
The aim of the present study was to describe the distribution of xerothermic species of vascular plants in the lower San River valley and the relationship between their density and the intensity of selected environmental (natural and anthropogenic) factors. Xerothermic species occurred more frequently in the present valley floor compared to the glacial terrace. Within the present valley, the highest density was observed in the floodplain. The examined species also occurred more often on steep slopes of the valley, at the margins of the present valley terraces, and in the area of occurrence of aeolian sands. Moreover, a positive correlation has been found between the number of xerothermic species and the area of polyhemeroby ecosystems. The distribution of xero- and thermophilous species is determined by natural edaphic and geomorphological factors as well as anthropogenic ones (land use, lowering of the groundwater level as a result of river regulation).
\end{abstract}

Key words: vascular flora, xerothermic plants, distribution, river incision, San River, SE Poland

\section{INTRODUCTION}

The group of dry and warm habitat plants, depending on the adopted criteria (syntaxonomy, ecological indicator values), may be recognized in various manners. In the narrow sense, they are the taxa associated with dry grasslands of the class Festuco-Brometea. However, this group often includes plants typical of other syntaxa like Trifolio-Geranietea, Koelerion glaucae, Onopordion, Agropyretea, Berberidion, Prunion fruticosae, and Quercetalia pubescenti-petraeae as well as a number of other species with a wider ecological amplitude, but most often occurring in thermophilous communities in the given region. Distingu- ishing a particular socio-ecological group based on one narrow criterion often causes a lot of good indicator species to be omitted.

In Poland, the distribution of xerothermic plants and communities is often associated with river valleys such as the Vistula, Odra, Warta, Bug, or Noteć (R a domski and Janowska, 1965; Ceynowa, 1968; Fi li pe k, 1974; K u c harc zy k, 2000, 2001; $\operatorname{Tr}$ ą $b$ a , 2010). In the landscape of river valleys, it is the steep and insolated slopes, usually rich in calcium and devoid of dense forest vegetation, which are the optimum for thermophilous plants. In such places typical dry grasslands, forest edges communities, thermophilous scrub and sparse forests are formed. However, apart from the optimal habitats, a certain number of xerothermic species is always present throughout the river valley. They most commonly occur in the drier parts of river terraces, erosion edges, pioneer and ruderal habitats. They grow on dry meadows and sandy grasslands, on balks, fallow lands, roadsides, scarps and in areas heavily transformed by man $(\mathrm{K} \mathrm{u} \mathrm{ch} \mathrm{a} \mathrm{r-}$ czyk, 2001; Skrzyczyńska and Rzymowska, 2001; S krzyczyńska and S tachowicz, 2007; Myśliw y, 2010).

The lower San flows through the Sandomierz Basin area whose Quaternary cover is mostly composed of sands (Buraczyński and Wojtanowicz, 1966; Kondracki, 2002). In addition, a significant part of the valley has a mature relief lacking of distinct slopes. Such conditions are not favourable to colonization by thermophilous plants. The paper presents the characteristic of the distribution of xerothermic vascular plant species in this river valley and the relationship between their density and selected natural and anthropogenic factors. 


\section{Study area}

The San is a medium-sized river with a drainage basin of $16779 \mathrm{~km}^{2}$. The mean annual discharge in the lowland section near Radomyśl is $123 \mathrm{~m}^{3} / \mathrm{s}$. The lower San valley is a wide erosion furrow (approximately 10 $\mathrm{km}$ wide) which has a complex system of river terraces. In the bottom of the valley, there are three main levels of terraces: floodplain, meadow (rendzina) terrace and glacial terrace, within which a few smaller steps can be distinguished (B u r a c z y ń s ki and W oj ta n ow icz, 1966; S zumański, 1982, 1986). The surface of the Pleistocene terrace area is occupied mainly by sandy podsolic soils. The present valley floor is filled with alluvial deposits, with mainly loamy soils on the meadow terrace and silty-sand soils in the floodplain (W o ndra u s h, 1954; P a sternak, 1963; S z u m a ń s k i , 1986). Distinct steep slopes occur only on short sections and they are covered with loamy landslides. The plateau is built of Miocene clays underlying the surface of diverse deposits of glacial, fluvioglacial and aeolian origin (B u r a c z y ń s k i and W ojt a n ow ic z, 1966; B u try m, 1968; W ojtanowic z, 1971).

The main river-control and embankment construction works were carried out at the turn of the $19^{\text {th }}$ century. This resulted in activation of deep erosion, a lowering of the water table (especially in the immediate vicinity of the river), and a reduction in the area of the active floodplain (W i $\mathrm{g}$ a t and $\mathrm{Kow}$ a $\mathrm{s} \mathrm{k} \mathrm{a}$, 1975; S z u m ań s ki , 1986; W y ż g a , 2008).

The Pleistocene terrace is largely covered in forests, while on the Holocene valley terraces agricultural landscape prevails. In the examined section of the valley, a medium-sized industrial town of Stalowa Wola is situated.

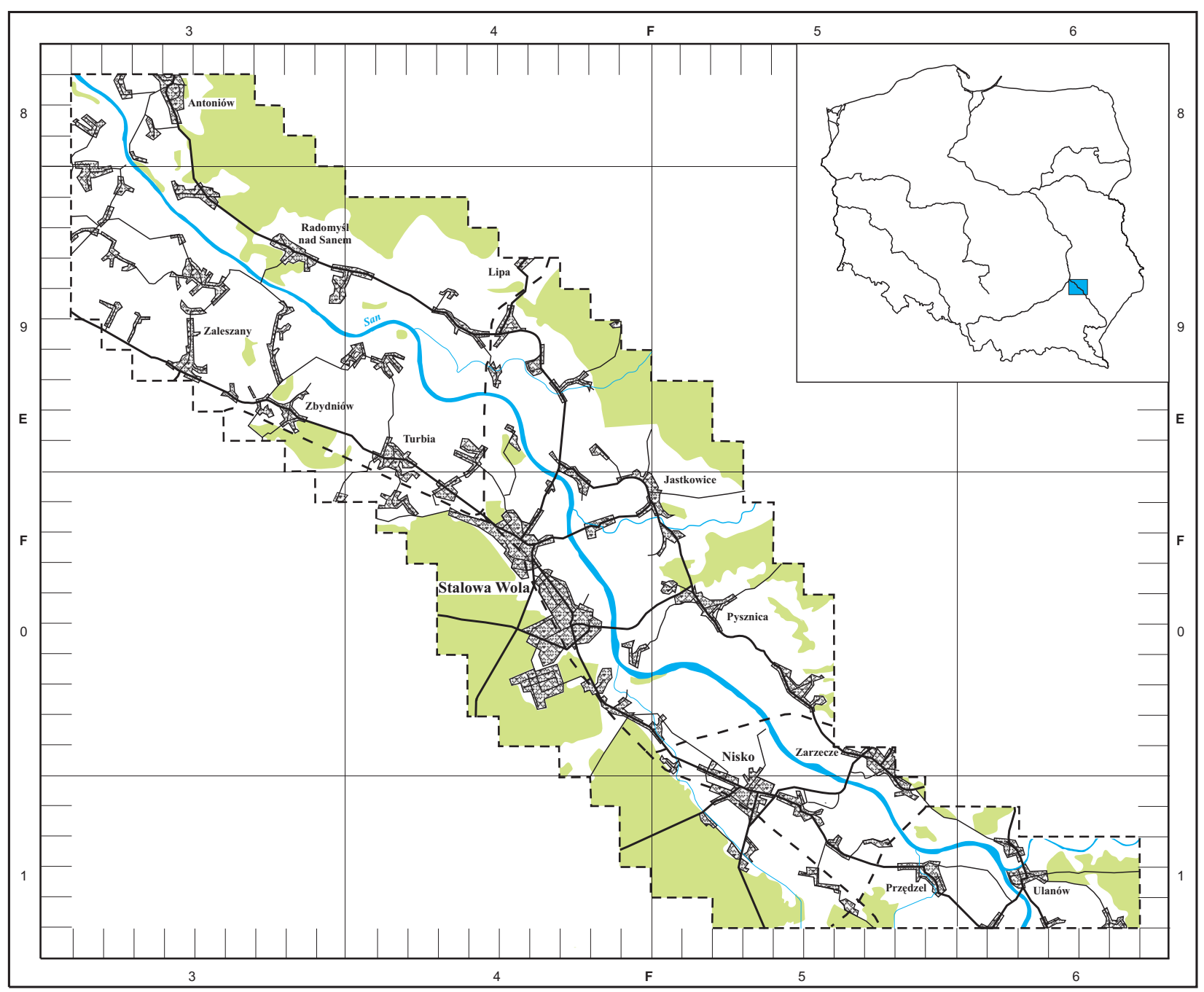

Fig. 1. Study area in ATPOL square grid 


\section{MATERIALS AND METHODS}

The distribution analysis of vascular plants was conducted on the basis of floristic data collected during the mapping of vascular flora in the years 20022008. A field investigation was carried out on a $50-\mathrm{km}$ section of the valley from Ulanów to the river mouth (Fig. 1). 106 species of vascular plants were used in the analysis. The selection of species was based primarily on a broad phytosociological criterion. The core of the selected group consisted of species characteristic (according to M a t u s z ki e w i c z 2005) of the Festuco-Brometea class as well as of the Geranion saguinei and Koelerion glaucae alliances. Moreover, taking into consideration the specificity of local vegetation, a number of other species growing mostly in dry and warm places were added.

During the field investigation, the ATPOL grid ( $\mathrm{Z} \mathrm{a} \mathrm{j} \mathrm{ą} \mathrm{c} \mathrm{,} \mathrm{1978)} \mathrm{was} \mathrm{applied} \mathrm{and} \mathrm{flora} \mathrm{of} 366$ basic plots of 1 square $\mathrm{km}$ was mapped. A cartogram presenting the concentration of selected species was made.

Spearman's rank correlation coefficient and the visual-comparative method (comparison of cartograms showing the investigated phenomena) were used in order to determine relationships between the density of the studied species and the intensity of selected environmental variables. The following factors were taken into account: the area of floodplain, meadow terrace, glacial terrace, present valley floor, steep slopes, plateau, aeolian sands, polyhemerobic ecosystems ( $\mathrm{S} \mathrm{u} \mathrm{k}$ k o p, 1969, 1972), and the length of the Holocene/ Pleistocene edge zone. The area of these elements of the environment was estimated as the percentage of coverage of basic plots adopting the following scales: 10-rank scale for relief elements $(1-1-10 \%, 2-$ $11-20 \%, 3-21-30 \%$, etc.), 5-rank scale for polyhemerobic ecosystems $(1-1-5 \%, 2-6-25 \%, 3-26-50 \%$, $4-51-75 \%, 5-76-100 \%)$. Being very specific systems, polyhemerobic ecosystems were treated comprehensively - they consist of technical infrastructure and the accompanying synanthropic vegetation. To determine the elements of relief, detailed geological maps and geomorphological literature were employed (B uraczyński and Wojtanowicz, 1966; Szumański 1982, 1986). The area of polihemerobic ecosystems was estimated based on orthophotomaps and field notes.

List of selected xerothermic species and their phytosociological affiliation is given below: Achillea collina (Fest-Brom), A. pannonica (Fest-Brom), Acinos arvensis (Fest-Brom), Agrimonia eupatoria (Trif-Ger), Ajuga genevensis (Fest-Brom), Allium oleraceum (Fest-Brom), Alyssum alyssoides (oth), Anchusa officinalis (Onop), Anthemis tinctoria (Fest-Brom), Anthericum ramasum (Trif-Ger), Anthyllis vulneraria (Fest-Brom), Arabis glabra (oth), A. hirsuta (Fest-Brom), Artemisia campestris (Fest-Brom), Asparagus officinalis (Fest-Brom), Astragalus cicer (Trif-Ger), A. glycyphyllos (Trif-Ger), Brachypodium pinnatum (Fest-Brom), Bromus erectus (Fest-Brom), B. inermis (Fest-Brom), B. tectorum (Sisym), Campanula glomerata (Fest-Brom), Carex caryophyllea (Fest-Brom), C. praecox (Fest-Brom), Carlina vulgaris (Fest-Brom), Centaurea scabiosa (Fest-Brom), C. stoebe (Fest-Brom), Cerasus fruticosa (Prun), Cerinthe minor (oth), Chamaecytisus ruthenicus (oth), Chondrilla juncea (Koel), Clematis recta (Trif-Ger), Clinopodium vulgare (Trif-Ger), Coronilla varia (Trif-Ger), Cynoglossum officinale (Onop), Dianthus arenarius (Koel), D. carthusianorum (Fest-Brom), Draba nemorosa (oth), Erigeron acris (Fest-Brom), Eryngium planum (oth), Euphorbia cyparissias (Fest-Brom), Falcaria vulgaris (Agrop), Festuca polesica (Koel), F. psammophila (Koel), F. rupicola (Fest-Brom), F. trachyphylla (oth), Filipendula vulgaris (Fest-Brom), Fragaria viridis (Trif-Ger), Geranium sanguineum (Trif-Ger), Gypsophila fastigiata (Koel), Hieracium bauhinii (Fest-Brom), Jovibarba sobolifera (Koel), Kochia laniflora (Koel), Koeleria glauca (Koel), K. macrantha (Fest-Brom), Lathyrus niger (Querc), L. sylvestris (Trif-Ger), Lavatera thuringiaca (oth), Lithospermum officinale (oth), Medicago falcata (Trif-Ger), Melampyrum arvense (Fest-Brom), Neslia paniculata (oth), Onobrychis viciifolia (Fest-Brom), Ononis spinosa (oth), Origanum vulgare (Trif-Ger), Petrorhagia prolifera (Fest-Brom), Peucedanum oreoselinum (Trif-Ger), Poa angustifolia (Agrop), Poa compressa (Fest-Brom), Polygala comosa (oth), Polygonatum odoratum (Trif-Ger), Potentilla alba (Querc), P. arenaria (Fest-Brom), P. collina (Koel-Coryn), P. recta (oth), $P$. rupestris (oth), Primula veris (oth), Pulmonaria mollis (Querc), Ranunculus bulbosus (oth), R. polyanthemos (Querc), Rosa gallica (oth), R. rubiginosa (Berb), Salvia pratensis (oth), S. verticillata (Fest-Brom), Sanguisorba minor (oth), Scabiosa ochroleuca (Fest-Brom), Sedum maximum (oth), Sedum sexangulare (Koel), Seseli annuиm (Fest-Brom), Silene chlorantha (oth), S. nutans (Trif-Ger), S. otites (Koel), Thalictrum minus (Trif-Ger), Thesium linophyllon (Fest-Brom), Thlaspi perfoliatum (Fest-Brom), Thymus pulegioides (oth), Trifolium medium (Trif-Ger), T. montanum (Arrh), Verbascum blattaria (Onop), V. lychnitis (Trif-Ger), Veronica spicata (Fest-Brom), Vicia cassubica (Trif-Ger), V. dumentorum (Trif-Ger) Vincetoxicum hirundinaria (oth), Viola hirta (Trif-Ger), V. rupestris (Fest-Brom), Viscaria vulgaris (oth).

Explanation of abbreviations: (Agrop - Agropyretea intermedio-repentis, Arrh - Arrhenatherion elatioris, Berb - Berberidion, Fest-Brom - Festuco-Brometea, Koel - Koelerion glaucae, Koel-Coryn - 
Koelerio glaucae-Corynephoretea canescentis, Onop - Onopordetalia acanthii, Prun - Prunion fruticosae, Sisym - Sisymbrietalia, Trif-Ger - Trifolio-Geranietea sanguinei, Querc - Quercetalia pubescenti-petraeaea, oth - others, not included in the Matuszkiewicz system)

\section{RESULTS}

Among the 106 species concerned, over 35\% are rare taxa $(<5 \%$ of the cartogram units), and only five of them can be regarded as widespread $(>50 \%$ of the cartogram units). Their concentration in basic plots ranged from 0 to 38 , with an average of 11.9. The study indicates a quite regular pattern of distribution of xerothermic plants in the San River valley. It is associated primarily with the location of the river terraces. Overall, the study area is characterized by greater density of the studied species on the Holocene terraces in comparison to the glacial terraces (Fig. 2, Table 1). Within the present valley, the largest number of studied species is observed on the floodplain. This relationship is most marked in areas where the high step of the floodplain is wide and distinctly separated. The species which seem to prefer this part of the valley include Astragalus cicer, A. glycyphyllos, Bromus erectus, Koeleria macrantha, Lathyrus sylvestris or Scabiosa ochroleuca. They inhabit dry meadows and pastures, wastelands, forests margins, and shrubs. Species of xerothermic communities appear slightly less frequently on the meadow terrace where they grow on erosion edges, balks, wastelands, roadsides, and Molinia meadows with fluctuating water table. Xerothermic plants reach their increased concentration on the margins of the present valley where the mud terrace changes over into the sandy glacial terrace (edge zone). In these places, Clematis recta, Seseli annuиm, and Rosa gallica can be encountered. The species more commonly found in the bottom of the whole present valley are, e.g., Agrimonia eupatoria, Filipendula vulgaris, Carex praecox, and Fragaria viridis.

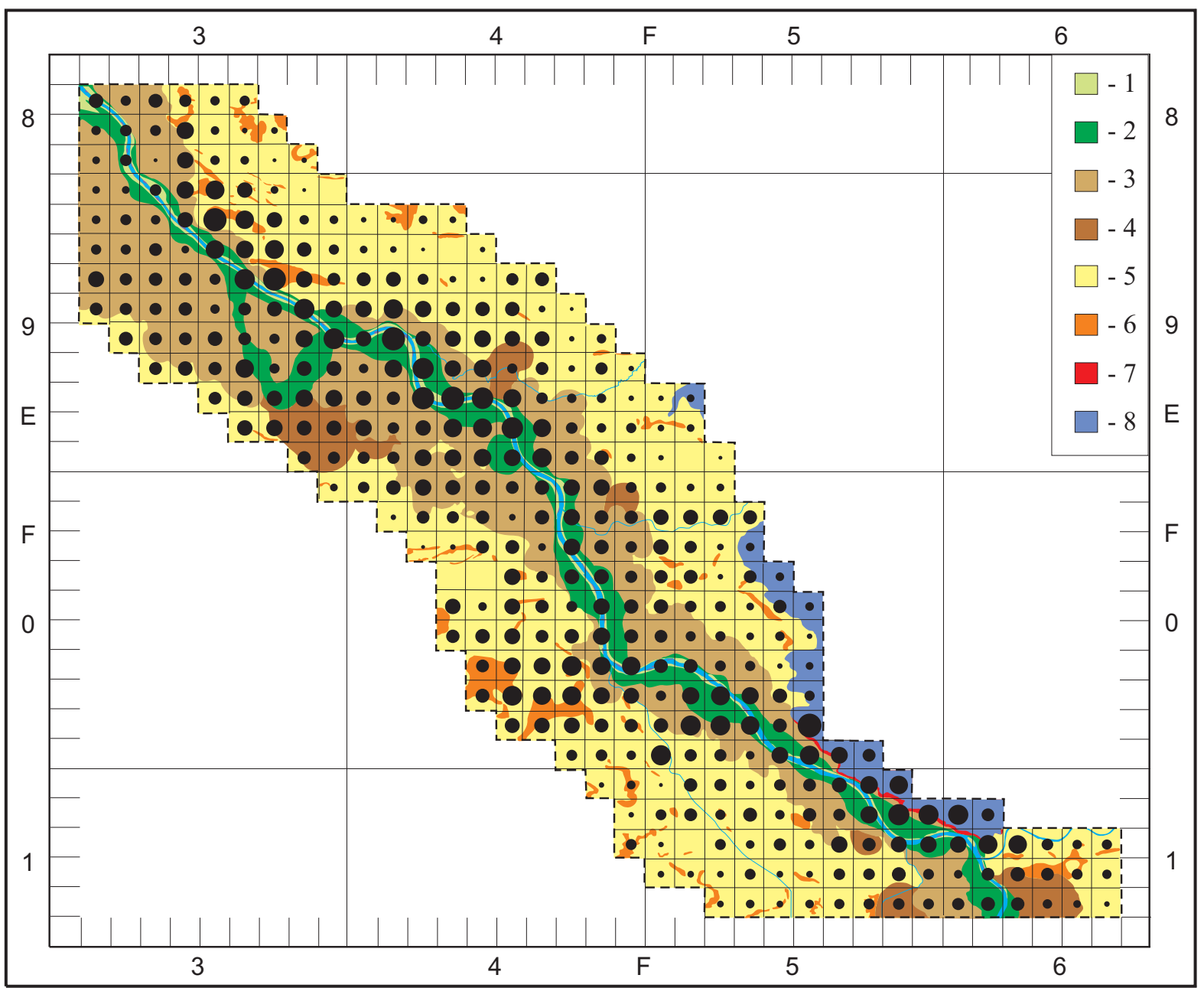

Fig. 2. Concentration of xerothermic species at the background of the San River valley relief. Explanation: 1, 2 - low and high level of floodplain, 3, 4 - low and high level of meadow (rendzina) terrace, 5 - glacial terrace, 6 - aeolian sands, 7 - steep slopes of the valley, 8 - mild slopes and plateau 
Table. 1

Spearman's rank correlation between number of xerothermic species and environmental variables

\begin{tabular}{lc}
\hline Floodplain & $0.49 ; \mathrm{p}<0.00001$ \\
\hline Meadow terrace & $0.31 ; \mathrm{p}<0.00001$ \\
\hline Present valley floor & $0.40 ; \mathrm{p}<0.00001$ \\
\hline Glacial terraces & $-0.42 ; \mathrm{p}<0.00001$ \\
\hline Steep slops of the valley & $0.25 ; \mathrm{p}<0.00001$ \\
\hline Plateau & $0.02 ;$ n.s. \\
\hline Aeolian sands & $-0.09 ;$ n.s. \\
\hline Present valley edges & $0.26 ; \mathrm{p}<0.00001$ \\
\hline Polyhemerobic ecosystems & $0.25 ; \mathrm{p}<0.00001$ \\
\hline
\end{tabular}

On the Pleistocene terrace, grassland species are rather rare components of the flora and they are only slightly more numerous in places of aeolian sands (visible in the comparative method). Dune areas are the optimum for Anthericum ramosum, Dianthus carthusianorum, Polygonatum odoratum, and Silene nutans. Steep slopes, closing the typical arrangement of the river valley, are a zone of frequent occurrence of xerothermic species. The species that clearly prefer this part of the valley are, e.g., Centaurea scabiosa and Vicia dumentorum.

A considerable proportion of xero- and thermophilous species take advantage of ruderal habitats which are developing in various parts of the valley (Table 1). A number of them, such as Acinos arvensis, Centaurea stoebe or Poa compressa, inhabit almost exclusively those places. A noticeable concentration of such species is observed in the vicinity of the town of Stalowa Wola, in its industrial parts as well as in residential areas.

\section{DISCUSSION}

Local distribution ranges of plants are determined by a specific combination of natural and anthropogenic factors. The reasons for the presented distribution pattern of xerothermic plants in the San River valley can be found in edaphic and geomorphological conditions as well as in the form of land use. The present valley floor is lined with meso- to eutrophic fine sediments, while the glacial terrace comprises mostly sandy oligotrophic substrates (B u raczyński and $\mathrm{W} \mathrm{o} \mathrm{j} \mathrm{t} \mathrm{a} \mathrm{n} \mathrm{ow} \mathrm{i} \mathrm{c} \mathrm{z,} \mathrm{1966).} \mathrm{The} \mathrm{latter} \mathrm{are} \mathrm{rather} \mathrm{reluc-}$ tantly occupied by typical xerothermic species, since they require soils which are slightly richer in nutrients and, most of all, which contain a certain amount of calcium carbonate. A greater concentration of xerothermic species found in the dune areas may result from a larger participation of the silt fraction in the substrate in some of their parts, e.g. dune lee-face slopes (B u try m, 1968; W o j t a n ow i c z, 1969).
The glacial terrace and the present valley bottom also differ very significantly in forms of land use. A vast part of the Pleistocene terraces is covered by forests which restrict the migration and territorial occupancy of xero- and heliophilous plants. On the other hand, the present valley floor is dominated by agricultural mosaic landscape which is favourable to them.

In the case of xerothermic plants occurring in the temperate humid climate zone, human activity plays a key role in forming suitable habitats; traditional extensive agriculture is particularly conducive to this process. The changing economic situation at the end of $20^{\text {th }}$ century enforced modifications in farming management activating changes in ecosystems of agricultural landscape (B a r a b a s z, 1994; K orn aś, 1990). A large part of farmlands, especially with low quality soils, was abandoned. It resulted in the emergence of a mosaic of labile phytocoenoses in various stages of succession (B a r a b a s z - K r a s n y, 2002; Trąba et al. 2004). Furthermore, wasteland burning, which was frequently applied in the San valley till the beginning of the $21^{\text {st }}$ century, was an important practice for the existence of xerothermic species. Thus, in the initial stage of the described transformations, there were still favorable environmental conditions for xerothermic plants. At present, in the San River valley and throughout the country, xeric open and sub-open communities decline rapidly.

The high concentration of xerothermic species on the San River floodplain is an interesting phenomenon. It seems that the main indirect cause of this situation is river regulation carried out more than 100 years ago. It consisted in straightening and, above all, narrowing of the wild river, which was at the time braided in character ( $\mathrm{S} \mathrm{z} \mathrm{u} \mathrm{m} \mathrm{a} \mathrm{ń} \mathrm{s} \mathrm{k} \mathrm{i} \mathrm{,} \mathrm{1986).} \mathrm{It} \mathrm{resulted} \mathrm{in}$ activation of deep erosion and river incising into the valley bottom. The scale of this phenomenon is varied; in the San valley, the depth of erosion incision varies from $3.1 \mathrm{~m}$ near Jarosław to $2 \mathrm{~m}$ at the point of Nisko (W y ż g a , 2008). The greatest intensity of 
erosion occurred in the second half of the $20^{\text {th }}$ century. The river incision results in the lowering of the water table, which is most visible in the floodplain built of permeable sandy sediments. Another consequence is a reduction in inundation area and a decrease in sedimentation of the material carried by the river during overbank flow and, as a result, a decrease in fertility of the habitats (Wilgat and Kowalska, 1975; S z u mań ski 1986; W y ż g a 2008). The occurrence of grassland species in the upper parts of the floodplain may be a natural phenomenon in the valleys of undisturbed water conditions, however, their significant concentration in comparison to other parts of the valley is certainly not a regularity and it is most likely the result of the process described above.

The phenomenon of intensive river incision has been reported, among others, from the territory of France (B r a vard et al. 1997). The authors of this study also presented the possible consequences of the impact of changes in water table level on alluvial floodplain vegetation. Thus, a lowering of the water table which does not exceed $1 \mathrm{~m}$ will have no impact on plant communities of the floodplain if the fluvial dynamics is preserved, while a reduction in excess of $3 \mathrm{~m}$ will result in significant changes in plant communities of all successional stages. An indication of the changes will be a large participation of xerothermic species typical of the valley slopes. A reduction in the range of 1-3 m will increase the proportion of xerophilous species in the group of herbaceous plants growing in the more permeable soils. It seems to be precisely the case in the examined section of the San valley. Over-dried silty-sand deposits and extensive farming on the floodplain create favourable conditions for the development of xerothermic vegetation. Detailed studies on the effects of river incision and the resulting changes in water conditions on flora dynamics will be conducted by the author in subsequent years in the Carpathian river valleys of the Sandomierz Basin.

By comparison, the distribution of species of xerothermic communities in the section of the middle Vistula River adjacent to the San River looks completely different. In the section of the Vistula explored by $\mathrm{K} \mathrm{u} \mathrm{charczyk}$ (2001), the highest density of xerothermic species can be observed on the valley's steep slopes, while on the floodplain it is very low. This is mainly due to the different nature and geographical location of the valleys and, to some extent, also to the degree of regulation of the two rivers. Unlike the lower San, the middle Vistula is located in the area of rocks rich in calcium carbonate and almost the entire length of the examined section has distinct steep slopes. Moreover, the Vistula remained for a long time (and in many section it still does) an unregulated river of braided character, and the bottom of the floodplain retains much more moisture in comparison with the San valley (S t a r k e 1, 2001; W a r ow na, 2003).

A greater participation of xero- and thermophilous species in heavily transformed areas is a widely known phenomenon reported from the area of many cities. This rule is confirmed by the results from the valley of the San. Polyhemerobic ecosystems are usually characterized by reduced moisture of the soil basement as a result of rapid evaporation and outflow of water as well as increased temperature, especially at the surface of the ground ( $\mathrm{S} \mathrm{udnik-W}$ ó cikowska, 1998; Jackowiak, 1998; Fortuniak, 2003; Witosławski and Bomanowska, 2008).

\section{CONCLUSIONS}

1. The distribution of xerothermic vascular plants in the lower San River valley is determined by both natural (edaphic and geomorphological) and anthropogenic (land use, river regulation) factors.

2. Xerothermic species occurred more frequently in the present valley floor filled with fine-grained alluvial soils compared to the sandy glacial terraces.

3. A considerable lowering of the water table caused by river regulation is probably the main cause of high density of xerothermic plants in the floodplain.

4. A positive correlation has been found between the number of xerothermic species and the area of polyhemeroby ecosystems.

\section{Acknowledgements}

Research supported by the Ministry of Science and Higher Education of Poland as the part of statutory activities of Department of Nature Conservation, Maria Curie-Skłodowska University in Lublin

\section{REFERENCES}

B arabasz B ., 1994. Wpływ modyfikacji tradycyjnych metod gospodarowania na przemiany roślinności łąk z klasy Molinio-Arrhenatheretea. / The effect of traditional management methods modifications on changes in meadow flora of the Molinio-Arrhenetheretea class. Wiad. Bot. 38 (1/2): 85-94 (in Polish).

B a rabasz-Krasny B ., 2002. Sukcesja roślinności na łąkach, pastwiskach i nieużytkach porolnych Pogórza Przemyskiego. / The succession of vegetation on the meadows, pastures and barren agricultural areas in the Przemyśl Foothills (south-eastern Poland). Fragm. Flor. Geobot. Polonica, Suppl. 4: 3-81 (in Polish).

Bravard J.P., Amoros C., Pautotou G., Bornette G., Bournaud M., Creuzé des Châtelliers M., Gilbert J., Peiry J.L., Perrin J.F., Tachet H., 1997. River incision in south-east France: morphological phenomena and ecological effects. Regulated Rivers, 13: 1-16. 
Buraczyński J., Wojtanowicz J ., 1966. Rozwój doliny Wisły i Sanu w czwartorzędzie w północnej części Niziny Sandomierskiej. / The development of the valleys of the Vistula and San rivers in the northern part of the Sandomierz Lowland during the Quaternary Era. Ann. UMCS, Sect. B, 21: 143-177 (in Polish).

Butry m J ., 1968. Utwory pyłowe wschodniej części Niziny Sandomierskiej. / Silty formations in the eastern part of the Sandomierz Lowland. Ann. UMCS, Sect. B, 23: 87127 (in Polish).

Cey nowa M., 1968. Zbiorowiska roślinności kserotermicznej nad dolną Wisłą. Stud. Soc. Sc. Torun. Sec. D 8(4): 1-156 (in Polish).

Filipek M., 1974. Murawy kserotermiczne regionu dolnej Odry i Warty. / Xerothermic swards of the lower Oder and Warta Region. Pr. Kom. Biol. PTPN, 38: 1-110 (in Polish).

Fortuniak K., 2003. Miejska wyspa ciepła. Wydawnictwo Uniwersytetu Łódzkiego, Łódź (in Polish).

Jackowiak B ., 1998. Struktura przestrzenna flory dużego miasta. Studium metodyczno-problemowe. Pr. Zakł. Taks. Roślin UAM w Poznaniu. Poznań, 8: 1-228. Bogucki Wydawnictwo Naukowe, Poznań (in Polish).

Kondracki J., 2002. Geografia regionalna Polski. Wydawnictwo Naukowe PWN, Warszawa (in Polish).

Kor n aś J., 1990. Jak i dlaczego giną nasze zespoły roślinne. / Recent decay of plant associations in Poland. Wiad. Bot. 34(2): 7-16 (in Polish).

Kucharczyk M., 2000. Plant association and communities of the Kazimierz Landscape Park. V. Xerothermic grassland and shrub associations. Ann. UMCS, Sect. C, 55: 183-220.

Kucharczyk M., 2001. Distribution Atlas of Vascular Plants in the Middle Vistula River Valley. Maria Curie-Skłodowska University Press, Lublin.

Matuszkiewicz W., 2005. Przewodnik do oznaczania zbiorowisk roślinnych Polski. Vademecum Geobotanicum 3. Wydawnictwo Naukowe PWN, Warszawa (in Polish).

Myśliw y M., 2010. Dynamics of xerothermic plants species in the upper River Płonia valley (NW Poland). Natura Montenegrina, Podgorica, 9(3): 389-401.

Pasternak K., 1964. Geologiczna i gleboznawcza charakterystyka dorzecza rzeki Sanu. / Geological and pedological characteristics of the basin of the San river. Acta Hydrobiol. 6: 167-215 (in Polish).

Radomski J., Ja nowska J., 1965. Roślinność zbiorowisk murawowych na zachodniej krawędzi doliny dolnej Odry. Część III. Charakterystyka muraw kserotermicznych na zachodniej krawędzi doliny dolnej Odry. Zesz. Nauk. WSR w Szczecinie, 19: 69-83 (in Polish).

Skrzyczyńska J., Rzymowska Z ., 2001. The segetal flora of the Bug river geomorphological territories in Podlasie region. Acta Agrobot. 54(1): 115-135.

Skrzyczyńska J., Stachowicz P., 2007. Flora of fallow lands of the Podlaski Przełom Bugu Mesoregion. Acta Agrobot. 60(1): 175-190.
St arkel L., 2001. Historia doliny Wisły od ostatniego zlodowacenia do dziś. Monografie Instytutu Geografii i Przestrzennego Zagospodarowania PAN, 2: 1-263 (in Polish).

Sudnik-Wójcikowska B ., 1998. Czasowe i przestrzenne aspekty procesu synantropizacji flory na przykładzie wybranych miast Europy Środkowej. Wydawnictwo Uniwersytetu Warszawskiego, Warszawa (in Polish).

Sukkop H., 1969. Der Einfluss des Menschen auf Vegetation. Vegetatio, 17: 360-371 (in German).

S u k k o p H., 1972. Wandel von Flora und Vegetation in Mitteleuropa unter dem Einfluss des Mensche. Ber. ü. Landwirtsch. 50: 112-139 (in German).

Szu mański A., 1982. The evolution of the lower San River valley during the Late Glacial and Holocene [In:] Evolution of the Vistula river valley during the last 15000 years, L. Starkel (ed.), Geographical Studies IG i PZ PAN, Spec. Iss. 1: 57-78.

Szu mański A., 1986. Postglacjalna ewolucja i mechanizm transformacji dna doliny Dolnego Sanu. / Late Glacial evolution and mechanism of transformation of the floor of the lower San valley. Kwart. AGH, Geologia 12(1): 5-92 (in Polish).

Trąba Cz., Wolański P., Oklejewicz K., 2004. Zbiorowiska roślinne nieużytkowanych łąk i pól w dolinie Sanu. / Plant communities of abandoned meadows and fields in the San valley. Łąk. Pol. 7: 207-238 (in Polish).

Trąba Cz., 2010. Różnorodność florystyczna i stan zachowania muraw kserotermicznych w okolicach Czumowa koło Hrubieszowa. [In:] Ciepłolubne murawy w Polsce. Stan zachowania i perspektywy ochrony, H. Ratyńska, B. Waldon (eds). Wydawnictwo Uniwersytetu Kazimierza Wielkiego, Bydgoszcz: 446-457 (in Polish).

Wa rowna J., 2003. Wpływ zabudowy hydrotechnicznej na warunki sedymentacji w korycie powodziowym Wisły na odcinku Zawichost-Puławy. Wydawnictwo Uniwersytetu Marii Curie-Skłodowskiej, Lublin (in Polish).

Wilgat T., Kowalska A., 1975. Wpływ działalności gospodarczej na stosunki wodne Kotliny Sandomierskiej. / The impact of economic activities upon hydrographic conditions in the Sandomierz Basin. Dok. Geogr. Instytutu Geografii i Przestrzennego Zagospodarowania PAN 5/6: 5-61 (in Polish).

Witosławski P., Bomanowska A., 2008. Spatial diversity of thermal preferences of vascular plants in Łódź. Biodiv. Res. Conserv. 11-12: 49-56.

Wojtanowicz J., 1969. Typy genetyczne wydm Niziny Sandomierskiej. / Genetic types of dunes of the Sandomierz Lowland. Ann. UMCS, Sect. B, 24: 1-45 (in Polish).

Wojtanowicz J., 1971. Wyspa lessowa koło Krzeszowa nad Sanem. / The loess island near Krzeszów on San. Ann. UMCS, Sect. B, 26: 67-88 (in Polish).

Wondrausch A., 1954. Mady okolic Niska i Rudnika n. Sanem. / Alluvial soils of San river near Nisko and Rudnik. Ann. UMCS, Sect. B, 7: 47-58 (in Polish). 
Wyżga B ., 2008. Wcinanie się rzek polskich Karpat w ciągu XX wieku. [In:] Stan środowiska rzek południowej Polski i możliwości jego poprawy - wybrane aspekty, B. Wyżga (ed.). Instytut Ochrony Przyrody PAN, Kraków: 7-39 (in Polish).

Zają c A., 1978. Założenia metodyczne „Atlasu rozmieszczenia roślin naczyniowych w Polsce". / Methodological assumption of Distribution atlas of vascular plants in Poland. Wiad. Bot. 22(3): 145-155 (in Polish).

\section{Wpływ naturalnych i antropogenicznych czynników na rozmieszczenie gatunków kserotermicznych w dolinie dolnego Sanu}

\section{Streszczenie}

Celem badań była charakterystyka rozmieszczenia kserotermicznych gatunków roślin w dolinie dolnego Sanu oraz określenie zależności pomiędzy ich zagęszczeniem a nasileniem wybranych czynników środowiskowych. Materiał do analizy został zebrany podczas kartowania flory naczyniowej w latach 2002-
2008. Kartowanie przeprowadzono w siatce kwadratów o boku $1 \mathrm{~km}$. Badania objęły teren o powierzchni $366 \mathrm{~km}^{2}$ (odcinek Ulanów-ujście Sanu). Do badań wytypowano 106 taksonów przywiązanych do siedlisk ciepłych i suchych. Relacje pomiędzy florą a czynnikami środowiskowymi oceniono metodami wizualno-porównawczą i statystyczną (współczynnik korelacji rang Speramana). Gatunki kserotermiczne występowały znacznie częściej na obszarze współczesnego dna doliny w porównaniu z terasą glacjalną. W obrębie współczesnej doliny największe zagęszczenie obserwowane było na obszarze terasy łęgowej. Badane gatunki częściej występowały również na stromych zboczach doliny, w strefie krawędziowej holoceńskiego dna doliny oraz na obszarze występowania piasków eolicznych. Stwierdzono ponadto dodatnią korelację pomiędzy liczbą gatunków kserotermicznych a powierzchnią ekosystemów polihemerobowych. Rozmieszczenie badanych gatunków uwarunkowane jest zarówno czynnikami naturalnymi (podłoże glebowe, rzeźba terenu) jak i antropogenicznymi (sposób użytkowania terenu, obniżenie poziomu wód gruntowych w wyniku regulacji rzeki). 